\title{
Lokale bivirkninger ved parenteral administrasjon av legemidler
}

\author{
Ved parenteral administrasjon av legemidler kan lokale bivirkninger \\ i sjeldne tilfeller være alvorlige og overskygge de tilsiktede behandlings- \\ effektene. Hvordan kan slike bivirkninger forebygges og håndteres?
}

Se også kunnskapsprøve på www.tidsskriftet.no/quiz

\section{Tormod Karlsen Bjånes}

tormod.karlsen.bjaanes@helse-bergen.no Seksjon for klinisk farmakologi Laboratorium for klinisk biokjemi Haukeland universitetssykehus 5021 Bergen

Parenteral administrasjon defineres som all tilførsel av legemidler utenom tarmen $(1,2)$. Parenteral administrasjon er egnet hos pasienter med nedsatt svelgefunksjon, der det er problemer med etterlevelse eller er plagsomme bivirkninger ved oral formulering og for legemidler som degraderes i tarmen eller gjennomgår høy førstepassasjemetabolisme i leveren. Det er også aktuelt der det trengs spesielt rask effekt, for eksempel ved behov for adrenalin, eller der man tilstreber langvarig stabil effekt, for eksempel smertelindring, slik transdermale opioider gir (3).

Bivirkninger opptrer med varierende hyppighet og alvorlighetsgrad, og kan oppstå både lokalt og systemisk. Denne artikkelen omhandler lokale bivirkninger ved parenteral behandling. Milde og selvbegrensende reaksjoner som smerte, hematomer og hudutslett forekommer hyppigst $(3,4)$. I sjeldne tilfeller ser man også alvorlige reaksjoner som krever målrettet behandling.

\section{Materiale og metode}

Grunnlaget for artikkelen er et ikke-systematisk litteratursøk i PubMed og EMBASE. Det ble gjort et skjønnsmessig utvalg av artikler ut fra forfatterens erfaring fra indremedisin og klinisk farmakologi. Transdermal administrasjon er utelatt, ettersom dette temaet nylig er omtalt i Tidsskriftet (5).

\section{Subkutan administrasjon}

Legemidler kan administreres subkutant som injeksjon, infusjon eller implantat. Subkutan administrasjon er aktuelt ved behov for langsom absorpsjon, for eksempel av hormonpreparater, og der det gjelder store molekyler som absorberes dårlig etter per- oral administrasjon, for eksempel insulin, hepariner og erytropoietin (3).

Vanligste komplikasjon til subkutane injeksjoner er hematomdanning på innstikksstedet. De fleste anbefaler en innstikksvinkel på 90 grader for å unngå dette. Samme vinkel ved innstikk og tilbaketrekking av kanylen synes imidlertid å være viktigere enn selve vinkelen (3). Tynn kanyle og liten sprøyte foretrekkes for å redusere injeksjonstrykket. Påføring av lokalt virkende antikoagulans, mukopolysakkaridpolysulfat, anvendes ofte ved etablerte subkutane hematomer og kan gi raskere tilheling sammenliknet med placebo eller ingen behandling (6).

Lipodystrofi ved insulinbehandling er fortsatt aktuelt, men forekommer sjeldnere etter innføringen av rekombinante insulinanaloger (7). Rotasjon av injeksjonssted og skifte av insulinnåler ved hver injeksjon praktiseres for å forebygge lipodystrofi (3, 7). Tabell 1 gir en oversikt over bruksområder og lokale bivirkninger ved parenteral

\section{Intramuskulær administrasjon}

Intramuskulær injeksjon benyttes der man ønsker rask absorpsjon, for eksempel av adrenalin ved anafylaksi, og gir lavere risiko for akutte systemiske bivirkninger enn intravenøs injeksjon. Intramuskulær administrasjon gir også mulighet for langsom frisetting av legemidler til systemkretsløpet, for eksempel antipsykotika i oljeoppløsning. Immunglobuliner og de fleste vaksiner gis intramuskulært, blant annet grunnet degradering i tarmen og fordi det er økt risiko for anafylaksi ved intravenøs injeksjon (3).

Vanligste lokale bivirkning etter intramuskulære injeksjoner er smerte ved innstikksstedet og i muskulaturen (3). Risikoen for smertereaksjoner kan reduseres ved forbehandling med lokalbedøvende krem og ved bruk av lang og tynn kanyle med lang skråskjæring til innstikket. Kort kanyle gir økt fare for injeksjon i fettvevet (fig la). Muskelsmerte kan skyldes volumeffekten av injektatet. Hos voksne anbefales inntil administrasjon.
$1 \mathrm{ml}$ i m. deltoideus og 2-4 $\mathrm{ml} \mathrm{i} \mathrm{m}$. vastus lateralis (3), hos barn under 15-16 år halvparten av disse volumene (8). Hvis det er behov for å gi større volum, anbefales det å dele dosen (3). Det er ikke vist at desinfeksjon av huden reduserer infeksjonsfaren, dette anbefales kun dersom huden er synlig tilsmusset $(3,8)$.

De fleste intramuskulære injeksjoner bør settes i $\mathrm{m}$. vastus lateralis eller fremre glutealregion. Det gjelder både voksne og barn (fig 1b). I klinisk praksis er det vanlig å velge bakre glutealregion, men dette innebærer høyere risiko for nerveskade og for utilsiktet injeksjon i subkutant fettvev $(3,9)$. NSAIDpreparater, for eksempel diklofenak, bør likevel settes $\mathrm{i}$ bakre glutealregion fordi det er kraftigere smertereaksjon og større fare for hudnekrose og abscessdanning ved injeksjon i andre muskler (3). Vaksiner bør settes i m. deltoideus (3). Hos barn under ett år bør $\mathrm{m}$. vastus lateralis benyttes på grunn av lavt muskelvolum i m. deltoideus $(3,8)$.

Hos pasienter med medfødte koagulasjonsdefekter eller hos dem som er under behandling med antikoagulantia praktiseres subkutan vaksinasjon på grunn av risikoen for muskulære hematomer. Det synes likevel å være trygt å gi influensavaksine, sannsynligvis også hepatittvaksine, intramuskulært til personer som får antikoagulasjonsbehandling (10).

Utstrålende smerter i forbindelse med innstikket tyder på at nålen berører en nerve. Injeksjonen må i så fall avbrytes og settes et annet sted. Skade på perifere nerver forekommer sjelden, og risikoen er minst ved innstikk i m. vastus lateralis. Prognosen for full tilheling etter nerveskader er generelt dårlig. I en rapport beregnet man at kun $28 \%$ oppnådde full tilheling (11).

\section{Hovedbudskap}

- Kunnskap om forebyggende tiltak og anbefalte administrasjonsteknikker reduserer risikoen for lokale bivirkninger

- Valg av injeksjonssted og -teknikk har betydning for komplikasjonsfrekvensen ved intramuskulære injeksjoner

- Alvorlige lokale bivirkninger kan oppstå ved ekstravasering av hyperosmolare løsninger og cytostatika 
Tabell 1 Bruksområder og lokale bivirkninger ved parenteral administrasjon

\begin{tabular}{|c|c|c|c|c|}
\hline Administrasjonsvei & Fordeler & Eksempler på legemidler & Lokale bivirkninger & Praktiske råd \\
\hline Alle & $\begin{array}{l}\text { Unngår førstepassasje- } \\
\text { effekt. } \\
\text { Kan gis når peroral } \\
\text { behandling ikke er aktuelt, } \\
\text { for eksempel ved bevisst- } \\
\text { løshet. }\end{array}$ & & $\begin{array}{l}\text { Milde reaksjoner på injek- } \\
\text { sjonsstedet, vanligst er } \\
\text { smerte, utslett, hematom }\end{array}$ & $\begin{array}{l}\text { Følg anbefalinger i pakningsvedlegg } \\
\text { og interne rutiner for forebygging } \\
\text { og håndtering av bivirkninger }\end{array}$ \\
\hline Subkutan & Langsom absorpsjon & $\begin{array}{l}\text { Insulin } \\
\text { Lavmolekylære hepariner } \\
\text { Erytropoietin }\end{array}$ & $\begin{array}{l}\text { Smerte, hematom, hud- } \\
\text { utslett, aseptisk nekrose }\end{array}$ & $\begin{array}{l}\text { Innstikksvinkel } 90 \text { grader } \\
\text { Tynn kanyle }\end{array}$ \\
\hline Intramuskulær & $\begin{array}{l}\text { Rask absorpsjon } \\
\text { Depoteffekter }\end{array}$ & $\begin{array}{l}\text { Adrenalin } \\
\text { Antipsykotika i oljeløsning } \\
\text { Vaksiner } \\
\text { Immunglobuliner }\end{array}$ & $\begin{array}{l}\text { Smerte, muskulære } \\
\text { hematomer, abscesser, } \\
\text { nerveskade }\end{array}$ & $\begin{array}{l}\text { Tilstrekkelig nålelengde. Unngå injek- } \\
\text { sjonsvolum > } 2-4 \mathrm{ml} \text {. } \\
\text { Injeksjon i m. vastus lateralis eller } \\
\text { fremre glutealregion (unntatt NSAID- } \\
\text { preparater). } \\
\text { Vaksiner settes i m. deltoideus (unntatt } \\
\text { hos barn < } 1 \text { år) }\end{array}$ \\
\hline Intravenøs & $\begin{array}{l}\text { Ingen absorpsjonsfase, } \\
\text { rask terapeutisk serum- } \\
\text { konsentrasjon }\end{array}$ & Anestesimidler & $\begin{array}{l}\text { Tromboflebitt, ekstra- } \\
\text { vasering }\end{array}$ & $\begin{array}{l}\text { Forsiktighet ved bruk av løsninger med } \\
\text { sterkt avvikende } \mathrm{pH}(<5,>9) \text { og osmola- } \\
\text { ritet }>350 \mathrm{mmol} / \mathrm{l} \text {, vasoaktive medika- } \\
\text { menter og cytostatika. } \\
\text { Skriftlige rutiner om ekstravasering }\end{array}$ \\
\hline Intraartikulær & Lokal behandlingseffekt & $\begin{array}{l}\text { Steroider } \\
\text { Lokalanestetika }\end{array}$ & $\begin{array}{l}\text { Septisk artritt, brusk- } \\
\text { nekrose }\end{array}$ & $\begin{array}{l}\text { Steril injeksjonsteknikk. } \\
\text { Maksimalt tre til fire årlige injeksjoner } \\
\text { i samme ledd }\end{array}$ \\
\hline Intraspinal & $\begin{array}{l}\text { Dermatomspesifikke } \\
\text { effekter, lav systemisk } \\
\text { eksponering }\end{array}$ & $\begin{array}{l}\text { Anestesimidler } \\
\text { Baklofen }\end{array}$ & Lekkasje av spinalvæske & $\begin{array}{l}\text { Tynn, ikke-skjærende nål } \leq 25 \mathrm{gg} \\
\text { Epidural blodlapp }\end{array}$ \\
\hline
\end{tabular}

\section{Snittbilde av intramuskulær injeksjon}

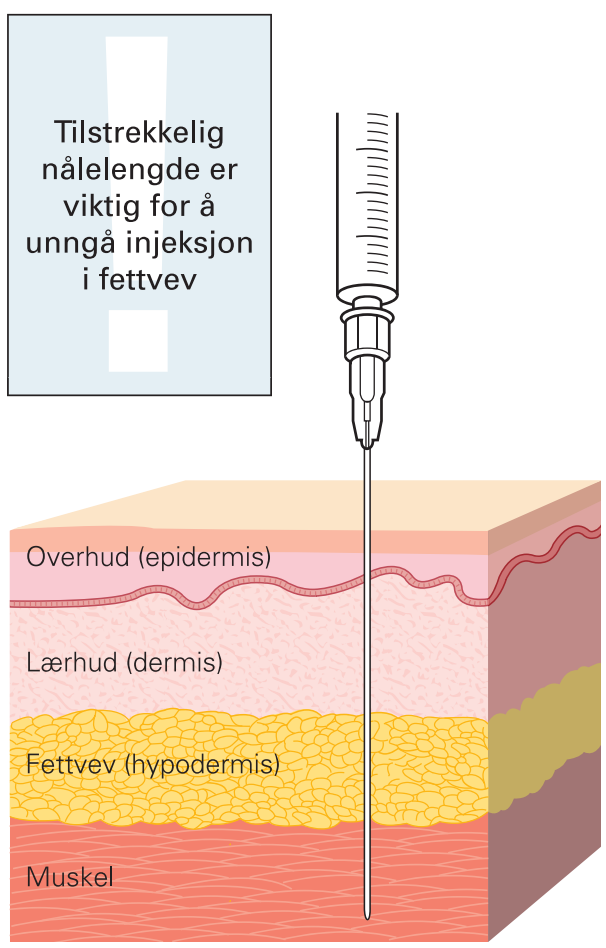

a

\section{Injeksjonssteder for intramuskulær injeksjon}

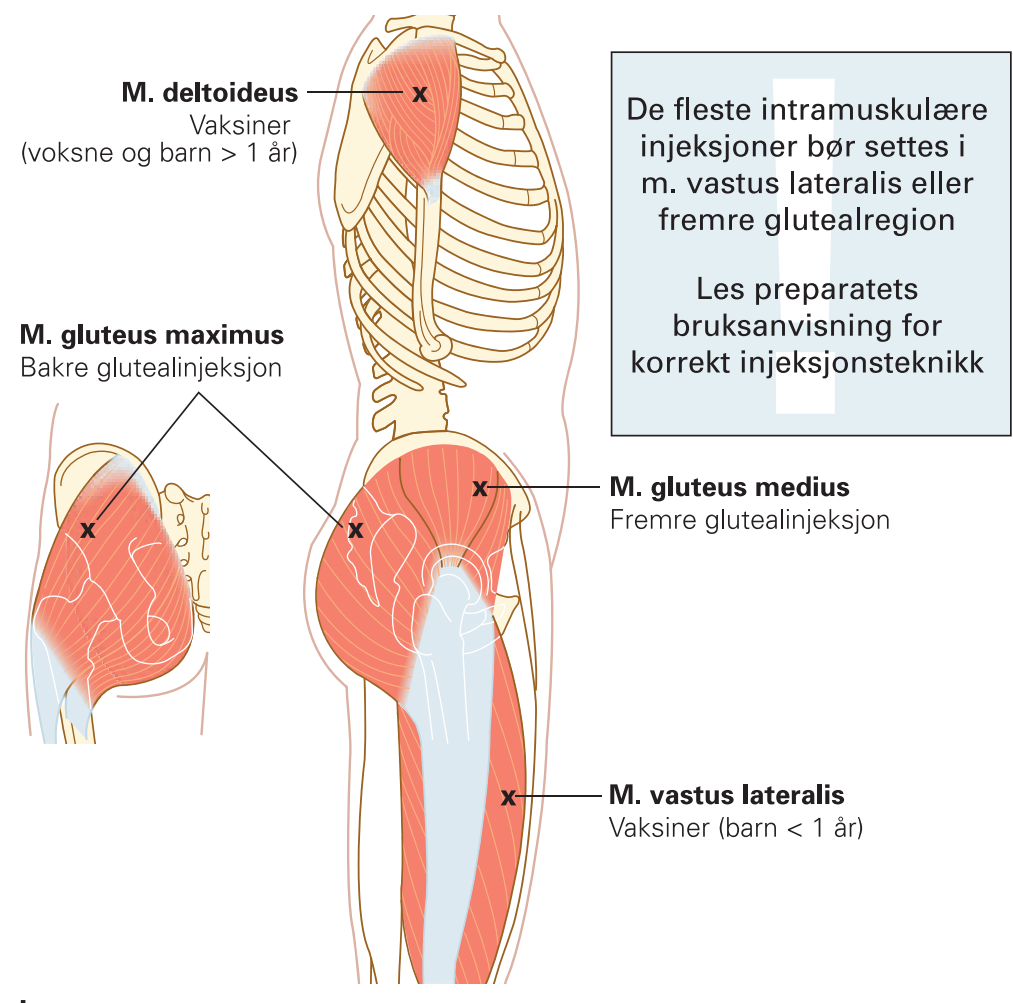

Figur 1 al Ved intramuskulær injeksjon må nålen være lang nok. b) Valg av injeksjonssted er viktig 


\section{Ramme 1}

\section{Tiltak ved ekstravasering $(11,12)$}

Stans infusjonen og koble fra infusjonssettet

Aspirer resterende legemiddel før venekanylen fjernes

Hold ekstremiteten hevet over hjertehøyde og i ro

Hold det kjølig lokalt ved ekstravasering av DNA-bindende cytostatika, kontrastvæske

og hyperosmolare løsninger

Hold det varmt lokalt ved øvrig ekstravasering (inkludert vinka-alkaloider).

Gi antidot (dimetylsulfoksid (DMSO) eller dexrazoxan) etter ekstravasering av antrasykliner

Be om kirurgisk tilsyn snarlig ved sterke smerter eller ved mistanke om dypere vevsskade. Aktuelle tiltak er:

- Gjennomskylling av vevet med sterilt saltvann (saltvannslavage)

- Debridement av nekrotisk vev og dekking med hudtransplantat

\section{Intravenøs administrasjon}

Intravenøs administrasjon er raskeste måte å oppnå terapeutisk serumkonsentrasjon av legemidler på og er foretrukket der det trengs rask effekt og for legemidler som absorberes dårlig eller gir uakseptable bivirkninger ved andre administrasjonsformer. Intravenøs infusjon er spesielt egnet for legemidler med kort halveringstid, og metoden gir mulighet for presis dosering, som ved narkose.

Lokale bivirkninger kan skyldes mekaniske forhold, for eksempel tynne og skjøre blodårer, ustabil kanyleposisjonering eller urolig pasient, fysiologiske forhold, som trombedanning proksimalt i blodkaret eller lokalisert lymfødem, eller farmakologiske faktorer, som osmolaritet, $\mathrm{pH}$, vasokonstriksjon eller cytotoksisitet (12).

Vanligste lokale bivirkning ved intravenøs behandling er tromboflebitt, som mest effektivt kan forebygges ved regelmessig skifte av venekanyle (6). Løsninger med osmolaritet $>350 \mathrm{mmol} / 1$ eller $\mathrm{pH}<5$ eller $>9$ virker irriterende på karveggen og gir økt risiko for ruptur (12). Eventuell ekstravasering kan gi opphav til store væskeskift og medføre smertefulle ødemtilstander og eventuell langvarig vevsskade. Spesielt gjelder dette parenterale ernæringsløsninger og plasmaekspanderende løsninger (12). Ekstravasering av vasoaktive substanser eller løsninger med høy elektrolyttkonsentrasjon kan utløse kraftig tonusøkning i perivaskulær glatt muskulatur, med iskemi og vevsnekrose som mulig konsekvens (12).

Ved administrasjon av cytostatika er eks- travasering spesielt uheldig $(12,13)$. Cytostatika kan inndeles i to grupper ut fra bindingsegenskaper til DNA. DNA-bindende cytostatika, for eksempel antrasykliner, vil ved ekstravasering raskt utløse vevsskade. DNA-antrasyklinkomplekser er lite tilgjengelige for metabolsk degradering og forblir i vevet i lengre tid, med fare for økt utbredelse av skaden. Ikke-DNA-bindende cytostatika, for eksempel plantealkaloider, medfører også celledød i affisert vev, men de degraderes raskere og gir en mer begrenset skade (13).

Håndtering av ekstravasering er av etiske grunner ikke undersøkt hos mennesker i kontrollerte studier. Eksisterende retningslinjer er derfor empiriske og basert på små observasjonsstudier, kasuistikker og dyrestudier. En ekspertgruppe publiserte i 2009 en anbefaling om håndtering av ekstravasering (12). Hovedpoenget er at forebygging er viktigst. Anbefalte tiltak er oppsummert i ramme 1 .

\section{Intraartikulær administrasjon}

Intraartikulær injeksjon av glukokortikoider og lokalanestetika benyttes ved lokaliserte inflammasjonstilstander. Rapportert insidens av septisk artritt etter intraartikulær injeksjon varierer fra én per 1000 til én per 50000 (4, 14). Degenerering av leddbrusk har vært vurdert som en mulig komplikasjon til gjentatte steroidinjeksjoner, men dette er ikke bekreftet i placebokontrollerte studier (14). Tre til fire årlige injeksjoner i ett enkelt ledd anføres som trygt i flere kilder $(4,14)$. Fluorinerte steroider, for eksempel triamcinolon og betametason, frarådes i småledd, ettersom disse kan medføre større fare for vevsnekrose enn de ikke-fluorinerte steroidene, for eksempel metylprednisolon (4).

\section{Intraspinal administrasjon}

Intraspinal administrasjon kan gi avgrensede dermatomspesifikke effekter med lave legemiddeldoser og lav systemisk eksponering. Foruten ved anestesiologiske prosedyrer benyttes intraspinal administrasjon for eksempel til spasmolyse ved multippel sklerose, mot leukemier og ved radiologiske prosedyrer.

Postspinal hodepine skyldes lekkasje av spinalvæske fra innstikksstedet $i$ dura og opptrer sjeldnere etter at bruk av tynne ( $\leq 25 \mathrm{gg})$, ikke-skjærende nåler er blitt vanlig $(4,15)$. I nyere studier rapporteres en insidens på 4-5\%, med overhyppighet hos unge kvinner (15). Epidural injeksjon av 15-20 ml autologt blod gir effektiv symptomlindring. Hos pasienter som får antikoagulerende midler og blodplatehemmere bør intraspinal administrasjon som hovedregel unngås grunnet fare for lokal blødning (4).

\section{Konklusjon}

Parenteral administrasjon av legemidler medfører risiko for en rekke lokale bivirkninger med ulik alvorlighetsgrad. De fleste reaksjonene er milde og selvbegrensende. Alvorlige reaksjoner kan blant annet oppstå ved ekstravasering av hyperosmolare løsninger og cytostatika. Administrasjon av slike midler krever derfor spesielle forsiktighetsregler. Kunnskap om forebyggende tiltak og bruk av anbefalte teknikker reduserer risikoen for lokale bivirkninger.

\section{Oppgitte interessekonflikter: Ingen}

\section{Litteratur}

1. Lindskog BI. red. Universitetsforlagets store norske medisinske ordbok. Oslo: Universitetsforlaget, 1998

2. Mathias NR, Hussain MA. Non-invasive systemic drug delivery: developability considerations for alternate routes of administration. J Pharm Sci 2010; 99: 1-20. doi:10.1002/jps.21793.

3. Aronson JK. Routes of drug administration: uses and adverse effects: Part 1: Intramuscular and subcutaneous injection. Adverse Drug React Bull 2008; 253: 971-4. doi:10.1097/

FAD.0b013e328329bb21.

4. Aronson JK. Routes of drug administration: uses and adverse effects: Part 2: sublingual, buccal, rectal, and some other routes. Adverse Drug React Bull 2009; 254: 975-8. doi:10.1097/ FAD.0b013e32832a0b18

5. Hupfeld S, Gravem H. Depotplastre som administrasjonsprinsipp for legemidler. Tidsskr Nor Legeforen 2009; 129: 532-3. doi:10.4045/ tidsskr.09.33349

6. Haas S, Breddin HK, Ottillinger B et al. Topical mucopolysaccharide polysulfate (MPS) in the treatment of thrombophlebitis - a critical review. Phlebologie 2001; 30: 132-9.

7. Del Olmo MI, Campos V, Abellán $P$ et al. A case of lipoatrophy with insulin detemir. Diabetes Res Clin Pract 2008; 80: e20-1. doi:10.1016/j.diabres. 2007.12.026.

8. Salisbury D, Ramsay M, Noakes K. red. Immunisation against infectious disease - The Green Book. London: Department of Health, 2006: 24-31 loppdatert i nettutgave: juni 2010).

9. Cocoman A, Murray J. Intramuscular injections: a review of best practice for mental health nurses. $J$ Psychiatr Ment Health Nurs 2008; 15: 424-34. doi:10.1111/j.1365-2850.2007.01236.x

10. Casajuana J, Iglesias B, Fàbregas M et al. Safety of intramuscular influenza vaccine in patients receiving oral anticoagulation therapy: a single blinded multi-centre randomized controlled clinical trial. BMC Blood Disord 2008; 8: 1. doi:10.1186/14712326-8-1.

11. Pandian JD, Bose S, Daniel V et al. Nerve injuries following intramuscular injections: a clinical and neurophysiological study from Northwest India. J Peripher Nerv Syst 2006; 11: 165-71. doi:10.1111/ j.1085-9489.2006.00082.x

12. Doellman D, Hadaway L, Bowe-Geddes LA et al. Infiltration and extravasation: update on prevention and management. J Infus Nurs 2009; 32: 203-11. doi:10.1097/NAN.0b013e3181aac042.

13. Schulmeister $L$. Extravasation management. Semin Oncol Nurs 2007; 23: 184-90. doi:10.1016/ j.soncn.2007.05.003.

14. Stephens MB, Beutler Al, O'Connor FG. Musculoskeletal injections: a review of the evidence. Am Fam Physician 2008; 78: 971-6.

15. O'Connor G, Gingrich R, Moffat M. The effect of spinal needle design, size, and penetration angle on dural puncture cerebral spinal fluid loss. AANA J 2007; 75: 111-6.

Mottatt 16.12. 2009, første revisjon innsendt 4.8. 2010, godkjent 30.9. 2010. Medisinsk redaktør Mette Sagsveen. 